УДК 343.97

DOI https://doi.org/10.51989/NUL.2021.6.19

\title{
ПРИНЦИПИ ФУНКЦІОНУВАННЯ СЕКТОРУ БЕЗПЕКИ I ОБОРОНИ УКРАЇНИ
}

\author{
Ромашко Олег Миколайович, \\ ORCID: 0000-0003-1601-1591 \\ старший викладач кафедри забезпечення державної безпеки \\ Київського інституту Національної гвардії України \\ Власов Олександр Геннадійович, \\ ORCID: 0000-0003-0641-1057 \\ старший викладач кафедри забезпечення державної безпеки \\ Київського інституту Національної гвардії України
}

Метою статті є комплексний аналіз принципів функціонування сектору безпеки і оборони України. У статті на підставі вивчення наукових напрацювань дослідників нормативно-правового підґрунтя функціонування сектору безпеки і оборони України автору вдалось обґрунтувати висновки щодо характеристики принципів функціонування сектору безпеки і оборони, змістовно розглянути зміст і сутність поняття «сектор безпеки і оборони України» та за допомогою аналізу нормативно-правового підґрунтя змістовно його наповнити. Додатково розглянуто зміст поняття про принципи і за допомогою аналізу наукових позицій дослідників автором обґрунтовано власне бачення щодо визначення окремих структурних елементів понятійно-категоріального апарату досліджуваної проблематики. Підкреслено, що поняття «сектор безпеки і оборони» визначається нормативно-правовими актами України, які не можуть трактуватись уявно, а лише суттєво і змістовно відображають, що саме відноситься до відповідного сектору.

Інтерпретовано наявні у законодавстві принципи державної політики у сфері національної безпеки і оборони та з'ясовано, що перша категорія принципів (до яких віднесено, зокрема, загальноправові принципи) регламентується Конституцією та законами України. Доведено, що група галузевих принципів відіграє найбільш значущу роль у розвитку всіх інституцій, які входять до сектору безпеки і оборони. Підкреслено можливість запозичення найкращих міжнародних практик; цей принцип виступає запобіжником регресу процесів стабільного розвитку. Зауважено, що участь в інтересах України у міжнародних зусиллях із підтримання миру і безпеки та у міждержавних системах гарантує поінформованість про реальний стан загроз для національної і державної безпеки. Доведено, що принцип розвитку формує статус сектору безпеки і оборони як ефективного механізму захисту прав і свобод людини та громадянина. Цей принцип, зокрема через задіння належних адміністративних і правових інструментів, уможливлює динамічний, стабільний і цілеспрямований розвиток сектору безпеки і оборони завдяки оцінці ризиків (як зовнішніх, так і внутрішніх) для держави, застосуванню стратегічного та галузевого планування у секторі безпеки і оборони України.

Ключові слова: принцип, сектор, безпека, оборона, сутність, зміст.

\section{Romashko Oleh, Vlasov Oleksandr. Principles of functioning of the security and defense sector of Ukraine}

The purpose of the article is a comprehensive analysis of the principles of functioning of the security and defense sector of Ukraine. In the article, based on the study of scientific developments of scientists, legal basis of the security and defense sector of Ukraine, the author was able to substantiate the conclusions on the characteristics of the principles of the security and defense sector, to consider the content and essence of the security sector-legal basis to fill it with content. In turn, the content of the concept of principles was additionally considered and by means of the analysis of scientific positions of scientists the author substantiated own vision, concerning definition of separate structural elements of the conceptual and categorical device of the investigated problems. It is emphasized that the concept of the security and defense sector is defined by regulations of Ukraine, which can not be interpreted imaginary, but only 
significantly and meaningfully reflect what exactly applies to the sector. The principles of state policy in the field of national security and defense are interpreted in the legislation and it is clarified that the first category of principles includes, in particular, common law principles regulated by the Constitution and laws of Ukraine. It is proved that the group of sectoral principles plays the most significant role in the development of all institutions in the security and defense sector. The possibility of borrowing the best international practices is emphasized, guided by this principle, which also acts as a safeguard against the regression of sustainable development processes. It is noted that participation in Ukraine's interests in international efforts to maintain peace and security and interstate systems guarantees awareness of the real state of threats to national and state security. It is proved that the principle of development forms the status of the security and defense sector as an effective mechanism for protecting human and civil rights. This principle, in particular through the use of appropriate administrative and legal instruments, enables dynamic, stable and purposeful development of the security and defense sector, including through risk assessment (both external and internal) for the state, application of strategic and sectoral planning in the security and defense sector. Of Ukraine.

Key words: principle, sector, security, defense, essence, content.

Актуальність тематики. Держава як соціальне об'єднання громадян вищої форми має низку функцій, реалізація та успішне виконання яких прямо впливає на рівень дотримання всіма, хто проживає у її межах, прав і свобод людини та громадянина. Нині стрімке підвищення ролі демократичних цінностей і розбудова правової державності у світі загалом та в Україні зокрема створюють підстави для вдосконалення функціонування окремих правових інститутів.

Серед інших важливих інституцій держави окремо розглядається сектор безпеки і оборони, що є цілісним механізмом, утвореним із засобів і заходів інституційного та суто правового характеру, діяльність (функціонування) яких спрямовані на забезпечення нормального розвитку держави і захисту ії від дестабілізаційних факторів. На нашу думку, визначення основних елементів, які забезпечують функціонування такого комплексного механізму, може наблизити державу до оптимізації його роботи і, відповідно, укріпити інститут прав і свобод людини та громадянина, для захисту якого і функціонує вищезазначений механізм.

Окрім того, слід підкреслити, що сектор безпеки і оборони є досить досліджуваним (як у галузі наук із державної безпеки, так і у сфері юриспруденції) такими відомими науковцями, як В. Бочарніков, М. Бутенко, В. Доронін, О. Каковкіна, В. Калашников, Н. Кулак, М. Лобко, М. Марченко, А. Михлін, Н. Огарков, В. Пилипчук, С. Поляков, С. Пономарьов, О. Скакун, Р. Тимошенко, А. Хворостянкін, М. Цвік, Ю. Шемшученко та багатьма іншими. Водночас, ураховуючи динамічний розвиток правової системи суспільства, а також недостатню, на нашу думку, дослідженість принципів функціонування сектору безпеки і оборони України, ми пропонуємо більш детально їх проаналізувати.

Метою роботи $\epsilon$ комплексний аналіз принципів функціонування сектору безпеки і оборони України. У свою чергу, поставлена мета зумовила потребу у розв'язанні низки дослідницьких завдань, а саме: 1) схарактеризувати поняття «сектор безпеки і оборони» та його зміст, виокремити перелік принципів його функціонування; 2) надати характеристику запропонованим науковцями принципам і виокремити із цього питання авторську позицію; 3) узагальнити опрацьований матеріал і сформувати основні рекомендації щодо оптимізації функціонування відповідного інституту в аспекті дослідження.

Об'єктом дослідження виступають суспільні відносини у сфері функціонування сектору безпеки і оборони України.

Предметом дослідження $\epsilon$ принципи функціонування сектору безпеки і оборони України.

Виклад основного матеріалу статті. На сучасному етапі державотворення права і свободи людини та громадянина перебувають у стані систематичного утвердження і постійного розширення. Водночас функціонування сектору безпеки і оборони суттєво підвищує рівень їхнього захисту, саме тому забезпечення належного функціонування відповідного інституту $\epsilon$ вкрай важливим. 
Н. Огарков, тлумачачи поняття «сектор безпеки і оборони держави» у словниковому виданні, підкреслює, що донині поняттями, які офіційно вживаються у цьому секторі, були і $\epsilon$ «сфера національної безпеки та оборони», «сфера воєнної безпеки», «воєнна сфера», «Воєнна організація держави» тощо. Крім того, автор підкреслює, що, на жаль, у багатьох наукових джерелах ці поняття трактуються різноманітно, а нині дедалі більше науковців у своїх працях зводять його до функціоналу тільки воєнної безпеки держави [1, с. 50]. Водночас слід підкреслити, що поняття «сектор безпеки і оборони» визначається нормативно-правовими актами України, які не можуть трактуватись уявно, а лише суттєво і змістовно відображають, що саме відноситься до відповідного сектору.

Водночас Тлумачний словник української мови під словом «сектор» розуміє: 1) частину кола, обмежену дугою і двома радіусами; 2) частину народного господарства із визначеними економічними і соціальними рисами; 3) відділ в установі або організації [2, с. 744]. Зазначене аргументує позицію автора про те, що сектор не $\epsilon$ окремою галуззю у структурі механізму безпеки і оборони, а це, власне, він і $\epsilon$, оскільки такі слова, як «сектор», «сфера», «галузь» у контексті тлумачення інститутів права та галузей державної політики, буквально відображають назву сфери правового регулювання.

С. Поляков наголошує на однозначності таких формулювань та, звертаючи увагу на сутність цього поняття, застерігає від закритого типу функціонування сектору безпеки і оборони, підкреслює необхідність залучення до контрольних процесів у середині інститутів громадянського суспільства [3]. Ми підтримуємо таку позицію, оскільки функціонування інститутів права у громадському суспільстві та правовій державі має бути прозорим, підзвітним і доступним. Однак усе ж слід зосередитися на окремих елементах його функціонування, які не можуть діяти публічно через загрозу витоку інформації та проведення щодо певних органів диверсійних дій із боку іноземних спецслужб.

Водночас С. Пономарьовим звернуто увагу на тому, що сектор безпеки і оборони
України $€$ сукупністю державних органів та організацій, покликаних гарантувати безпеку особи, суспільства і держави. Автором також доведено, що відносини, пов'язані із державним регулюванням сектору безпеки і оборони, $є$ предметом адміністративного права, оскільки виникають між суб'єктами публічної влади, регламентуються адміністративно-правими нормами і мають управлінський, правоохоронний та публічно-сервісний характер [4]. Ми цілком підтримуємо таку позицію, оскільки питання організації функціонування сектору безпеки і оборони України (державних інститутів та інституцій права) визначаються в Законах України, Указах Президента України, постановах Кабінету Міністрів України та інших нормативноправових актах організаційно-розпорядчого характеру.

Поряд із науковим тлумаченням Законом України «Про національну безпеку України» визначається, що сектор безпеки і оборони - це система органів державної влади, Збройних Сил України, інших утворених відповідно до законів України військових формувань, правоохоронних та розвідувальних органів, державних органів спеціального призначення із правоохоронними функціями, сил цивільного захисту, оборонно-промислового комплексу України, діяльність яких перебуває під демократичним цивільним контролем, а також громадян і громадських об'єднань, котрі добровільно беруть участь у забезпеченні національної безпеки України [5]. Відповідно до Конституції та законів України за функціональним призначенням ця діяльність спрямована на захист національних інтересів України від загроз.

На нашу думку, сектором безпеки і оборони України $€$ взаємопов'язаний комплекс нормативно-правових актів організаційного характеру та органів державної влади, який за своєю сутністю створює правовий (інституційний) фундамент для забезпечення безпеки держави і суспільства, а також забезпечення обороноздатності України.

Водночас С. Пономарьов звертає увагу на те, що відповідно до головних видів безпеки, які дістали поширення в Україні, існує три основних елементи сектору безпеки: 1) особиста безпека громадян, 
громадський порядок, які забезпечуються правоохоронними органами; 2) національна безпека (забезпечується спецслужбами); 3) військова безпека (забезпечується Воєнною організацією України) [4]. На нашу думку, ця градація загалом відображає зміст і сутність функціонування сектору безпеки і оборони України, проте потребує доповнення у частині адаптації до норм чинного законодавства (наприклад, автором указується поняття про національну, громадську безпеку, але не зазначається публічна безпека, забезпечення котрої $\epsilon$ однією з основних цілей діяльності Національної поліції України).

Окрім цього, як зазначалось авторами на початку статті, основою функціонування будь-якого інституту $є$ принципи, що встановлюють чіткі межі його діяльності, а також слугують обмеженням, забезпечуючи реалізацію діяльності механізму стримувань і противаг у державному управлінні.

Словникові видання поняття «принцип» тлумачать як основну засаду, вихідну ідею, що характеризується універсальністю, загальною значущістю, вищою імперативністю і відображає суттєві положення теорії, учення, науки, системи внутрішнього і міжнародного права; політичної, державної чи громадської організації (гуманізм, законність, справедливість, рівність громадян перед законом тощо) [6, с. 560]. Тому принцип, будучи інтегрованим у механізм безпеки і оборони, виступає не лише правовою підставою функціонування, але і індикатором меж дозволеного, встановлює основоположні, базові засади функціонування у конкретній сфері.

Відомий правознавець О. Скакун неодноразово у своїх працях звертала увагу на те, що принципами у праві $\epsilon$ основоположні загальноприйняті норми, які виражають властивість права і мають вищу імперативну юридичну силу [7, с. 258]. Ми цілком поділяємо таку позицію і звертаємо увагу на те, що принципи сектору безпеки і оборони України мають імперативну юридичну силу, подекуди і вищу, оскільки основні засади функціонування галузі публічної, громадської, національної і державної безпеки вказані у Конституції України. Потреба у встановленні принципів відповідного сектору у визначений законодавством України спосіб є аксіомою.
Водночас, розглядаючи галузеві тлумачення поняття «принцип», нами досліджено позицію К. Каковкіної, яка розглядає «принципи політики» та визначає їх як загальні керівні основи, що походять із вимог політики держави і пронизують усю діяльність органів та установ виконання кримінальних покарань [8]. Інші автори вказують, що система принципів у праві (на прикладі кримінально-виконавчого права) охоплює загальні принципи права, принципи галузей права, які регулюють різні соціальні сфери буття у державі, а також принципи політики держави у різних галузях державного управління, зокрема і в галузі безпеки і оборони України [9].

Отже, на нашу думку, принципами сектору безпеки і оборони України $\epsilon$ основоположні норми, які спрямовують діяльність інституту безпеки і оборони України, регламентовані у передбачений законодавством України спосіб, і забезпечують досягнення мети функціонування сектору безпеки і оборони України.

Наприклад, згаданим вище Законом України «Про національну безпеку України» визначається, що основними принципами, які визначають порядок формування державної політики у сферах національної безпеки і оборони, $є$ :

1) верховенство права, підзвітність, законність, прозорість і дотримання засад демократичного цивільного контролю за функціонуванням сектору безпеки і оборони та застосуванням сили;

2) дотримання норм міжнародного права, участь в інтересах України у міжнародних зусиллях із підтримання миру і безпеки, міждержавних системах та механізмах міжнародної колективної безпеки;

3) розвиток сектору безпеки і оборони як основного інструменту реалізації державної політики у сферах національної безпеки і оборони [5]. Ми цілком підтримуємо такий підхід до визначення принципів державної політики у сфері національної безпеки і оборони, що, на нашу думку, може бути застосовано до всього сектору безпеки і оборони, котрий містить також забезпечення публічної, громадської, а також державної безпеки України, а не тільки національну безпеку як засадничу категорію. 
Інтерпретовано наявні у законодавстві принципи державної політики у сфері національної безпеки і оборони та з'ясовано, що перша категорія принципів, до яких віднесено, зокрема, загальноправові принципи (верховенство права, підзвітність, законність, прозорість і дотримання засад демократичного цивільного контролю за функціонуванням сектору безпеки і оборони та застосуванням сили), що регламентуються Конституцією та законами України, уможливлює на базовому (фундаментальному) рівні забезпечення функціонування сектору безпеки і оборони України у тісному взаємозв'язку та у контексті основного завдання держави - забезпечення правами і свободами всіх людей і громадян.

Друга група принципів, на нашу думку, відіграє найбільш значущу роль у розвитку всіх інституцій, які входять до сектору безпеки і оборони. Якщо йдеться про органи охорони публічного і громадського правопорядку, то слід підкреслити можливість запозичення найкращих міжнародних практик, керуючись таким принципом, який виступає запобіжником регресу процесів стабільного розвитку. Під час застосування відповідних принципів до функціонування 3бройних Сил України, а також до суміжних органів влади (військової розвідки та інших) участь в інтересах України у міжнародних зусиллях із підтримання миру і безпеки та у міждержавних системах гарантує поінформованість про реальний стан загроз для національної і державної безпеки, що в разі ефективного реагування позитивно відобразиться на функціонуванні інституту прав і свобод людини та громадянина.

Третій принцип, суто галузевий - це принцип розвитку, що формує статус сектору безпеки і оборони як ефективного механізму захисту прав і свобод людини та громадянина. Зокрема, цей принцип через задіяння належних адміністративних і правових інструментів уможливлює динамічний, стабільний і цілеспрямований розвиток сектору безпеки і оборони завдяки оцінці ризиків (як зовнішніх, так і внутрішніх) для держави, застосуванню стратегічного та галузевого планування у секторі безпеки і оборони України.

Висновки. Отже, на підставі дослідження наукових напрацювань нормативно-правового підґрунтя функціонування сектору безпеки і оборони України авторам удалось обґрунтувати висновки щодо характеристики принципів функціонування сектору безпеки і оборони, змістовно розглянути зміст і сутність поняття «сектор безпеки і оборони України», за допомогою аналізу нормативно-правового підґрунтя змістовно його наповнити. У свою чергу, додатково розглянуто зміст поняття «принципи» і за допомогою аналізу наукових позицій дослідників авторами обґрунтовано власне бачення визначення окремих структурних елементів понятійно-категоріального апарату досліджуваної проблематики.

\section{ЛITEPATУРA:}

1. Военный энциклопедический словар. Пред. гл. ред. комиссии Н. В. Огарков. Москва : Воениздат, 1984. 863 с.

2. Тлумачний словник української мови: понад 12500 статей (близько 40000 слів). За ред. д-ра філол. наук, проф. В. С. Калашникова. 2-ге вид., випр. і доп. Харків : Прапор, 2006. 992 с.

3. Поляков С. Ю. Особливості статусу та місце Збройних Сил України у структурі сектора оборони держави. Часопис Київського університету права. 2013. №3. URL: http://surl.li/unoc

4. Пономарьов С. П. Адміністративно-правове забезпечення діяльності сектору безпеки і оборони України : дис. докт. юр. наук : 12.00.07. Дніпро, 2018. 511 с.

5. Про національну безпеку України: Закон України від 21 червня 2018 року № 2469-VIII. Відомості Верховної Ради (ВВР). 2018. № 31. Ст.241. URL: https://zakon.rada.gov.ua/laws/ show/2469-19\#Text

6. Юридична енциклопедія: В 6 т. Редкол. Ю. С. Шемшученко (голова редкол.) та ін. Київ : «Укр. енцикл.», 1998. ISBN 966-7492-00-1 Т.5: П-С. 2003. 736 с. ISBN 966-7492-05-02.

7. Скакун О. Ф. Теорія держави і права: підручник. Харків: Консум, 2001. 656 с.

8. Каковкина Е. H. Шпаргалка по уголовно-исполнительному праву. URL: http:// lib.rus.ec/b/204798/ read.

9. Михлин А.С., Пономарев П.Г., Селиверстов В.И., Шмаров И.В. Уголовно-исполнительное право: учеб. для юрид. вузов. Под ред. проф. В.И. Селиверстова. 2-е изд. Москва : Юриспруденция, 2000. 320 с. 